\title{
Development of soil water regime under spruce stands
}

\author{
Ladislav Tužinský ${ }^{1 *}$, Eduard Bublinec ${ }^{2,3}$, Marek Tužinský $^{4}$
}

${ }^{1}$ Faculty of Forestry, Technical University in Zvolen, T.G. Masaryka 24, 96053 Zvolen, Slovak Republic ${ }^{2}$ Department of Biology and Ecology, Faculty of Education, Catholic University in Ružomberok, Hrabovská 1, 03401 Ružomberok, Slovak Republic

${ }^{3}$ Institute of Forest Ecology of the Slovak Academy of Sciences, Štúrova 2, Zvolen, Slovak Republic ${ }^{4}$ Faculty of Forestry and Wood Sciences, Czech University of Life Sciences Prague, Kamýcká 129, 16521

Praha 6 - Suchdol, Czech Republic

\begin{abstract}
TuŽInský, L., Bublinec, E., TuŽInskÝ, M., 2017. Development of soil water regime under spruce stands. Folia Oecologica, 44: 46-53.

The aim of this paper is to analyse the water regime of soils under spruce ecosystems in relation to long-lasting humid and drought periods in the growing seasons 1991-2013. The dominant interval humidity in observing growing seasons is semiuvidic interval with soil moisture between hydro-limits maximal capillary capacity (MCC) and point of diminished availability (PDA). Gravitationally seepage concentrated from accumulated winter season, water from melting snow and existing atmospheric precipitation occurs in the soil only at the beginning of the growing season. The supplies of soil water are significantly decreasing in the warm climate and precipitant deficient days. The greatest danger from drought threatens Norway spruce during the summer months and it depends on the duration of dry days, water supply at the beginning of the dry days, air temperature and the intensity of evapotranspiration. In the surface layers of the soil, with the maximum occurrence of active roots, the water in semiarid interval area between hydro-limits PDA and wilting point (WP) decreases during the summer months. In the culminating phase occurs the drying to moisture state with capillary stationary and the insufficient supply of available water for the plants. Physiological weakening of Norway spruce caused by set of outlay components of the water balance is partially reduced by delivering of water by capillary action from deeper horizons. In extremely dry periods, soil moisture is decreasing also throughout the soil profile $(0-100 \mathrm{~cm})$ into the bottom third of the variation margin hydro-limits MCC-PDA in the category of capillary less moving and for plants of low supply of usable water $(60-90 \mathrm{~mm})$. The issue of deteriorated health state of spruce ecosystems is considered to be actual. Changes and developments of hydropedological conditions which interfere the mountain forests represent the increasing danger of the drought for the spruce.
\end{abstract}

\section{Key words}

available water, forest ecosystem, hydrolimits, soil moisture, water balance

\footnotetext{
*Corresponding author: e-mail: tuzinskyladislav@gmail.com
} 


\section{Introduction}

Several forest ecosystems in Slovakia are more or less anthropogenically altered. This mainly holds for spruce forests, with the health status unsatisfactory in many cases. There is an urgent need for the care and protection of vulnerable ecosystems and for implementation of measures to control the processes threatening the ecosystems health and development. In summary, the interaction between vegetation and the surrounding environment, is today significantly affected by changes in biotic and abiotic components of the natural environment. The current research findings show that the preservation, safeguarding and enhancement of ecological stability of forest ecosystems can only be achieved through interdisciplinary research and optimal management.

A necessary condition for the existence, growth and development of forest ecosystems is understanding the processes occurring in the hydrosphere of the air and soil environment. Water balance means several components such as evapotranspiration, runoff conditions and water regime of soil. Soil moisture is the result of the coupling of atmospheric, soil and ground water in the soil environment. To ensure the appropriate soil fertility, the moisture is needed to accumulate and move to the plant roots in amounts required by the plant (ANTAL and ŠPÁNIK, 1999). The effects of climate change, exposure to extreme types of weather conditions (prolonged abundant rainfall or drought periods) cause soils waterlogging or drying out which creates conditions for the occurrence of hydropedological cycles with very different supply of water available for plants. Changes in the hydrological regime mean also the changes to site and soil characteristics, particularly the physical and chemical soil properties, physiological parameters, matter and energy metabolism (BUBLINEC, 1994; KMEŤ et al., 2009; STŘELCOVÁ et al., 2009; ŠACH et al., 2014; TUŽINSKÝ, 2004). As the result, considerable changes in the risk factors to the climate may appear (LoRz et al., 2010).

The subject of this paper is an analysis of the soil moisture profile in saline soil under a spruce stand in relation to individual components of the water balance (interception, evapotranspiration and runoff conditions). In the $20 \mathrm{~cm}$ soil surface layer and across the physiological soil profile we also analysed supply of usable water and performed environmental classification of soil moisture. The research run in the Upper Orava region in 1991-2013.

\section{Materials and methods}

The research site grown mostly with Norway spruce trees (Picea abies (L.) Karst.), 85\%, Fagus sylvatica $13 \%$, Abies alba 2\%) was established in 1984, for monitoring the chemistry of precipitation. Since 1991, the research has been expanded to study also the water balance components. The stand age at establisment was 80 years, stocking 0.8 , engaging $90 \%$. The typology has been assigned to the group of forest types Fageto Abietum. The soil type is cambisol modal acidic. The site is located at an altitude of $940 \mathrm{~m}$, on a south-oriented slope with a $15 \%$ inclination.

The local climate is cold, with an average annual temperature of $5{ }^{\circ} \mathrm{C}$, in the growing season $11^{\circ} \mathrm{C}$, with annual rainfall of over $1,000 \mathrm{~mm}$ and the highest monthly sums in June and July (Table 1).

Table 1. Climatic characteristics (according to $\mathrm{SHMI}^{1}$, 1998)

\begin{tabular}{|c|c|c|c|c|c|c|c|c|c|c|c|c|c|c|}
\hline Station & XI & XII & I & II & III & IV & $\mathrm{V}$ & VI & VII & VIII & IX & $\mathrm{X}$ & Year & $\mathrm{GS}^{2}$ \\
\hline \multicolumn{15}{|c|}{ Air temperature $\left({ }^{\circ} \mathrm{C}\right)$} \\
\hline \multirow{3}{*}{$\begin{array}{c}\text { Oravská } \\
\text { Polhora, Rabča } \\
\text { 1951-1980 }\end{array}$} & 1.4 & -2.8 & -5.1 & -4.1 & -0.9 & 4.5 & 9.5 & 13.1 & 14.6 & 14.1 & 10.3 & 5.8 & 5.0 & 11.0 \\
\hline & \multicolumn{14}{|c|}{ Precipitation (mm) } \\
\hline & 66 & 69 & 68 & 63 & 61 & 66 & 92 & 130 & 143 & 109 & 78 & 68 & 1,013 & 618 \\
\hline
\end{tabular}

${ }^{1}$ Slovak Hydrometeorological Institute, ${ }^{2}$ growing season.

Soil moisture was monitored in ten-day intervals, gravimetrically from soil samples obtained by soil drilling, into a depth of $100 \mathrm{~cm}$, in $10 \mathrm{~cm}$ layers. The samples consisted of 3 to 5 replications from the same sampling site, or there were composite samples containing material from 5 sampling sites. The soil sampling was arranged in a cross pattern in the central part of the spruce stand. The instantaneous moisture of the collected soil samples was determined after drying at a temperature of $105^{\circ} \mathrm{C}$ and expressed in $\%$ of volume. The following hydrophysical characteristics were determined: maximal capillary capacity (MCC) by Novak (in KLIKA et al., 1954), point of diminished availability (PDA) and wilting point (WP) according to DRBAL (1965). Soil texture was determined using the floating process proposed by Kopecký (in HrAŠKo et al., 1962), soil density pycnometrically and the volume density was derived by calculation. 
Water balance is determined by the formula:

$$
\mathrm{W}_{1}+\mathrm{R}=\mathrm{P}_{\mathrm{v}}+\mathrm{R}_{\mathrm{s}}+\mathrm{E}_{\mathrm{t}}+\mathrm{W}_{2}(\mathrm{~mm}),
$$

where $\mathrm{W}_{1}$ is the soil water amount at the beginning of observation period, $\mathrm{R}$ is the precipitation volume, $\mathrm{P}_{\mathrm{v}}$ is the vertical water seepage into the soil, $\mathrm{R}_{\mathrm{s}}$ is the surface runoff, $\mathrm{E}_{\mathrm{t}}$ is the evapotranspiration, and $\mathrm{W}_{2}$ is the amount of soil water at the end of the observation period.

Precipitation penetrating through the canopy was intercepted into rain gauge troughs made of galvanized steel with an intercepting area of $2,000 \mathrm{~cm}^{2}$, in 5 repetitions, located in a cross arrangement.

Stemflow was observed in three spruce trees with a diameter $\mathrm{d}_{1,3} 24 \mathrm{~cm}$ and a height of 21, 22 and $22.5 \mathrm{me}$ ters with the aid troughs of lead sheet wrapped around the stem perimeter.

Throughfall through the forest canopy and herbal cover was measured at a depth of $100 \mathrm{~cm}$, using lysimetres with an interception area of $343 \mathrm{~cm}^{2}$.

Surface runoff was studied by the method of deluometre layout - troughs and containers for collecting runoff from areas from 0.75 to 3 square meters.

Water consumption for evapotranspiration was calculated from the difference between the initial and final supply of water in the soil with regard to the other components of the water balance (interception, stem-flow, surface runoff).

The amount of water available to plants was calculated by subtracting the lacking water from the instantaneous soil moisture. The boundary between the lacking and physiologically accessible water was wilting point (WP). The supply of usable water was evaluated by KuTíLEK (1966), ecological classification of soil water regime by the same author (KUTíLEK, 1971).

\section{Results and discussion}

The study of water balance in natural environment is far from easy, as the interacting components represent a complex system. In case of forest ecosystems, there are coupled effects of environmental conditions, specific influence on forest microclimate and water balance components: interception, stemflow, evapotranspiration, desuction, hydrophysical soil properties. This results in a significant variability in soil moisture conditions. The amount and accessibility of soil water primarily depends on the ratio of the input and output components of the water balance.

In the studied spruce forest, precipitation is the only input component of water balance. Over the whole research period 1991-2013, the total precipitation in the growing seasons was $13,000 \mathrm{~mm}$, in particular years ranging from 350 (2003) to $775 \mathrm{~mm}$ (1991). The spruce trees retained on average $24.5 \%$ of precipitation in the open area, stemflow and surface run-off amounted to 0.5 to $1 \%$ on average. The water amount ran off below the lower limit of the balance soil profile $(>100 \mathrm{~cm})$ was on average $36 \%$ of soil water from the total amount of atmospheric precipitation, evapotranspiration represented from 21 to $42 \%$ (Table 2 ).

Table 2. Water balance in spruce ecosystems ( $\mathrm{mm})$

\begin{tabular}{|c|c|c|c|c|}
\hline $\mathrm{T}$ & $\mathrm{P}$ & I & WS & ET \\
\hline \multicolumn{5}{|c|}{ Growing season with subnormal precipitation } \\
\hline \multirow[t]{2}{*}{$12.3-13.1\left({ }^{\circ} \mathrm{C}\right)$} & $350-489$ & $96-130$ & $117-196$ & $130-186$ \\
\hline & $57-79 \%$ & $16-21 \%$ & $19-32 \%$ & $21-30 \%$ \\
\hline \multicolumn{5}{|c|}{ Growing season with normal precipitation } \\
\hline \multirow[t]{2}{*}{$11.8-13.1\left({ }^{\circ} \mathrm{C}\right)$} & $590-614$ & $130-156$ & $242-305$ & $144-195$ \\
\hline & $95-99 \%$ & $21-25 \%$ & $39-49 \%$ & $23-32 \%$ \\
\hline \multicolumn{5}{|c|}{ Growing seasom with above normal precipitation } \\
\hline \multirow[t]{2}{*}{$11.3-13.3\left({ }^{\circ} \mathrm{C}\right)$} & $719-775$ & $189-233$ & $266-312$ & $231-259$ \\
\hline & $116-125 \%$ & $31-38 \%$ & $43-50 \%$ & $37-42 \%$ \\
\hline
\end{tabular}

$\mathrm{T}$, average annual temperature; P, precipitation; I, interception; WS, water seepage; ET, evapotranspiration.

The greatest variability in temperature conditions and precipitation totals was observed in the summer months, with the biggest differences in the long-term average (1951-1980). The most favourable rainfall conditions were in September (95\%), the least precipitation fell in May (61\%), in the summer months (July,
August) fell $79 \%$ and $80 \%$, respectively, of the long-term average precipitation. The average annual temperature varied between $11.3^{\circ} \mathrm{C}$ to $13.3^{\circ} \mathrm{C}$, which means an average increase by $1.6^{\circ} \mathrm{C}$. The atmospheric precipitation minimum during the growing season for Norway spruce in the amount of 400 to $500 \mathrm{~mm}$ (TuŽINSKÝ, 
2004; ŠKVARENINA et al., 2000) was achieved in most cases. Drought danger for spruce stands occurred in periods with uneven distributed precipitation and during long lasting deficits of precipitation.

Precipitation with a daily sum of $<2.0 \mathrm{~mm}$ prevailed, representing the upper limit of the spruce water holding capacity. Minimal effect on the soil moisture was found in the precipitation category with a daily sum of 2 to $5 \mathrm{~mm}$. Significant increases in humidity were observed following daily sums beyond $10 \mathrm{~mm}$.

\section{Soil water regime}

The soil water regime is the result of the combination of income (input) and expenditure (output) components of the water balance. Existence, growth and development of the forest, in our case of spruce ecosystem, in context of water and soil, depend primarily on the infiltration and accumulation of soil water in the rhizosphere layer, or the environment with the highest incidence of active roots. In the case of spruce, this mostly means the soil surface and middle layers of soil $(0-50 \mathrm{~cm})$. These are subject to the greatest changes in the water regime linked to the changing climatic conditions.

Analysis of wetting, wetting duration and stratification of soil moisture according to the hydrolimites in the vegetation periods revealed that the most common was moisture intervals (Š́́TOR, 1994; ŠúTOR et al., 2005) within the lowest third of the interval between the maximal capillary capacity (MCC) and the wilting point (WP), in periods with decreased rainfall, close to the lower limit.

The evolution of the soil moisture balance provides evidence that the temperature- and precipitation-induced changes to the soil moisture were the highest in the surface layers of the soil, in the spring months ranging from 31 to $44 \%$ vol., in the summer months from 15 to $28 \%$ vol.

Within the $20 \mathrm{~cm}$ soil surface, two soil moisture intervals were alternated: uvid interval, mostly in spring months, limited by full water capacity (FWC) and MCC. The highest values with gravitationally seeping water and a good supply of usable water were recorded in 1991, 1994, 1995, 1998, 2001, 2003-2007 and 2010. The water increase was participated by the stock accumulated during winter season, the water from the melting snow and the current atmospheric precipitation.

The cycle of wetting and drying phases in the next vegetation period was dependent on the ongoing weather conditions, especially temperature and rainfall. Below the lower limit of the governing soil moisture interval (MCC-WP), soil moisture fell only in longer dry days. The occurrence of drought periods with limited or insufficient water supply in the surface soil layers was detected in the vegetation periods 1999, 2000, 2006, 2012 and 2013 (Table 3). The highest water losses occurred in the early days of the dry periods. On days with a relatively good soil water supply and relatively high air temperature $\left(>20^{\circ} \mathrm{C}\right)$, the main factor enhancing the water consumption was evapotranspiration representing a daily water consumption more than $4 \mathrm{~mm}$. Combined effects of the processes of water redistribution in the soil by macroporous filtration and by pumping water by spruce roots, caused a significant decrease, up to exhaustion, in the available water reserves in the rhizospheric soil layer, occurring in a relatively short time (5 to 10 days). The deficit of water balance during the dry periods gradually decreased, the maximum value of $-29 \mathrm{~mm}$ was recorded in the longest drougt period of the growing season 2013 (Table 3).

In the middle and deepest layers of the soil physiological profile $(40-100 \mathrm{~cm})$, the soil moisture dynamics was affected less strongly, with the deficit in the plant-accessible water only after longer-lasting drought periods. The largest deficit of usable water occurred in the just mentioned dry period $2013(-69.2 \mathrm{~mm})$, negative water deficit also resulted from the water balance values in $1992(-43.3 \mathrm{~mm}), 1999(-68.7 \mathrm{~mm})$ and 2012 $(-66.5 \mathrm{~mm})$.

During drought episodes within the growing season and due to specific hydraulic conductivity of dry soil, there arises a danger of moisture stress with various impacts on water balance components, the course of physiological processes (KozLOWSKI 1991; KonôPKA, 2009; Priwitzer et al., 2003; VerbeEK et al., 2007), gradual loss of active roots and changes in the root hydrotropism.

The most endangered soil surface layer is the relatively thick humus layer with a large amount of accumulated contaminants. In this layer, the osmotic pressure of soil solution increases, thus raising the critical level of the wilting point.

A partially regulated water regime may have a positive influence during periods with reduction of usable water deficit in the soil surface layers. In these periods, water is redistributed through active roots and pumped through capillary rise from deeper horizons (PERSSON et al., 1995; JENík, 1957).

As for the prevailing soil moisture stratification across the physiological profile, the soil moisure dynamics of moisture seemed more favourable. The dominant interval was the semiuvidic interval. In the growing seasons with the precipitation above normal, the moisture varied mostly in the upper third of the semiuvidic interval. In the first half of the growing season the humidity ranged from 23 to 36 vol. \%, the levels in the other periods, with the exception of the mentioned dry periods, did not fall below the threshold point of diminished availability PDA ( $<20$ vol. \%).

Differentiation of soil moisture influenced by climatic conditions, especially the precipitation timing is evident from the graphic representation using chronoizoplets in two growing seasons with normal precipitation in Fig. 1 and 2. The difference was between the timing of disintegration of the precipitation and mois- 
Table 3. Water supplies in the dry periods of the growing season

\begin{tabular}{|c|c|c|c|c|c|c|c|c|c|}
\hline \multirow{2}{*}{ GS } & & \multirow{2}{*}{$\frac{\mathrm{T}}{\left({ }^{\circ} \mathrm{C}\right)}$} & \multirow{2}{*}{$\frac{P}{(\mathrm{~mm})}$} & \multicolumn{2}{|c|}{$\mathrm{W}(\mathrm{mm})$} & \multicolumn{2}{|c|}{ AW (mm) } & \multicolumn{2}{|c|}{ CAW } \\
\hline & & & & $0-20 \mathrm{~cm}$ & $0-100$ & $0-20$ & $0-100$ & $0-20$ & $0-100 \mathrm{~cm}$ \\
\hline \multirow{2}{*}{1992} & 1.8. & \multirow{2}{*}{15.6} & \multirow{2}{*}{3.9} & 65.7 & 271.1 & 43.2 & 154.5 & $\mathrm{G}$ & $\mathrm{G}$ \\
\hline & 21.8. & & & 46.8 & 208.3 & 24.3 & 91.7 & $\mathrm{~S}$ & $\mathrm{~S}$ \\
\hline \multirow{2}{*}{1993} & 1.8. & \multirow{2}{*}{14.4} & \multirow{2}{*}{6.6} & 75.4 & 371.5 & 52.9 & 254.9 & $\mathrm{G}$ & $\mathrm{VG}$ \\
\hline & 22.8. & & & 63.2 & 232.5 & 27.6 & 115.9 & $\mathrm{~S}$ & $\mathrm{~S}$ \\
\hline \multirow{2}{*}{1994} & 19.7. & \multirow{2}{*}{17.1} & \multirow{2}{*}{4.1} & 73.6 & 349.9 & 51.1 & 233.3 & G & VG \\
\hline & 5.8. & & & 51.8 & 226.5 & 29.3 & 110.9 & $\mathrm{~S}$ & $\mathrm{G}$ \\
\hline \multirow{2}{*}{1995} & 4.8. & \multirow{2}{*}{15.0} & \multirow{2}{*}{1.8} & 67.5 & 252.7 & 45.0 & 136.1 & $\mathrm{G}$ & $\mathrm{G}$ \\
\hline & 23.8. & & & 45.7 & 214.5 & 23.2 & 97.9 & $\mathrm{~S}$ & $\mathrm{~S}$ \\
\hline \multirow{2}{*}{1998} & 1.8. & \multirow{2}{*}{14.7} & \multirow{2}{*}{15.6} & 70.9 & 417.6 & 48.4 & 301.0 & G & VG \\
\hline & 20.8. & & & 43.4 & 298.5 & 20.9 & 181.9 & G & VG \\
\hline \multirow{2}{*}{1999} & 19.8. & \multirow{2}{*}{14.2} & \multirow{2}{*}{6.5} & 50.3 & 217.3 & 27.8 & 100.7 & $\mathrm{~S}$ & $\mathrm{~S}$ \\
\hline & 25.9. & & & 39.1 & 182.9 & 16.6 & 66.3 & IS & $\mathrm{L}$ \\
\hline \multirow{2}{*}{2000} & 4.8. & \multirow{2}{*}{16.8} & \multirow{2}{*}{2.8} & 60.2 & 334.7 & 37.7 & 218.1 & $\mathrm{~S}$ & VG \\
\hline & 24.8. & & & 39.5 & 253.2 & 16.7 & 136.6 & IS & $\mathrm{G}$ \\
\hline \multirow{2}{*}{2003} & 30.7 . & \multirow{2}{*}{15.1} & \multirow{2}{*}{1.2} & 69.8 & 342.5 & 47.3 & 225.9 & $\mathrm{G}$ & VG \\
\hline & 13.8. & & & 41.5 & 273.4 & 19.0 & 156.8 & IS & $\mathrm{G}$ \\
\hline \multirow{2}{*}{2006} & 1.7. & 187 & 82 & 57.9 & 291.4 & 35.4 & 174.8 & $\mathrm{~S}$ & VG \\
\hline & 29.7. & 18.7 & 8.2 & 36.7 & 215.3 & 14.2 & 98.7 & IS & $\mathrm{S}$ \\
\hline 2007 & 11.7. & & & 75.8 & 331.9 & 53.3 & 215.3 & $\mathrm{G}$ & VG \\
\hline 2007 & 26.7. & 19.3 & 0.0 & 52.6 & 249.4 & 30.1 & 132.8 & $\mathrm{~S}$ & $\mathrm{G}$ \\
\hline & 20.7 & & & 59.3 & 225.3 & 27.3 & 95.3 & $\mathrm{~S}$ & $\mathrm{~S}$ \\
\hline 2012 & 10.8 & 17.3 & 7.2 & 40.6 & 198.5 & 8.6 & 68.5 & IS & $\mathrm{L}$ \\
\hline & 11.7. & & & 56.3 & 260.7 & 24.3 & 130.7 & $\mathrm{~S}$ & $\mathrm{G}$ \\
\hline 2013 & 30.8 . & 17.1 & 16.7 & 51.2 & 195.8 & 19.2 & 65.8 & IS & $\mathrm{L}$ \\
\hline
\end{tabular}

GS, growing season; T, temperature; P, precipitation; W, water supply; AW, available water.

CAW, categories of available water: VG, very good; G, good; S, sufficient; L, low; IS, insufficient.

ture conditions at the beginning of the growing season. The semiarid interval maintaining in the soil surface and middle layers in the vegetation period 1993, was caused by a long precipitation-defficient period in spring (Fig. 1). In May and June, there were only 15 precipitation days, including 11 with daily precipitation total less than $2 \mathrm{~mm}, 3$ precipitation events with a total of 5-10 $\mathrm{mm}$, and one event with a total of $17.6 \mathrm{~mm}$. The soil moisture was within hydrolimits PDA and WP, in the surface layers with less capillary water with sufficient water, or hardly accessible water. The moisture condition in the surface soil depth of $20 \mathrm{~cm}$ was the same during the main part of the growing season, in shorter episodes in the middle layers.

The drought risk threatening spruce owing to the reduced water supplies in the surface layers maintained unchanged, even after a series of richer precipitation events in June, July and August $(376 \mathrm{~mm}=94 \%$ of normal), until September. In the middle and deeper layers, the change occurred after an increased rainfall in the second half of June. The course of such a condition can be explained by the increase in water consumption for evapotranspiration $\left(>4 \mathrm{~mm}\right.$ day $\left.^{-1}\right)$ following the higher rainfall in June and July and the water seeping into the deeper horizons $(>36 \%)$. The drought was also caused by precipitation deficit in the first and second decades of August, during which there were 7 days with precipitation sum of 16.7 millimetres of water, from which four showed a daily total less than $2 \mathrm{~mm}$.

In the growing season 1995, with a more evenly distributed precipitation compared to 1993, moisture stratification throughout the physiological profile was mostly normal (Fig. 2). The semiuvidic soil moisture interval (MCC-PDA) with water mostly gravity-percolating and a good supply of usable water at the start of the growing season, was followed, beginning with the second half of May, by semiarid interval characterised with sufficient usable water supply.

In the second half of June and in August, after a series of higher precipitation totals, moisture increase to the semiarid interval was only in the layer $0-30 \mathrm{~cm}$. In the deeper layers of the soil physiological profile (60-100 $\mathrm{cm})$, the moisture maintained within semiarid intervals.

The presence of higher precipitation sums after drought periods rushed a rapid renewal of transpiration (Priwitzer et al., 2003) and caused certain time shift of water supply from deeper soil horizons. 


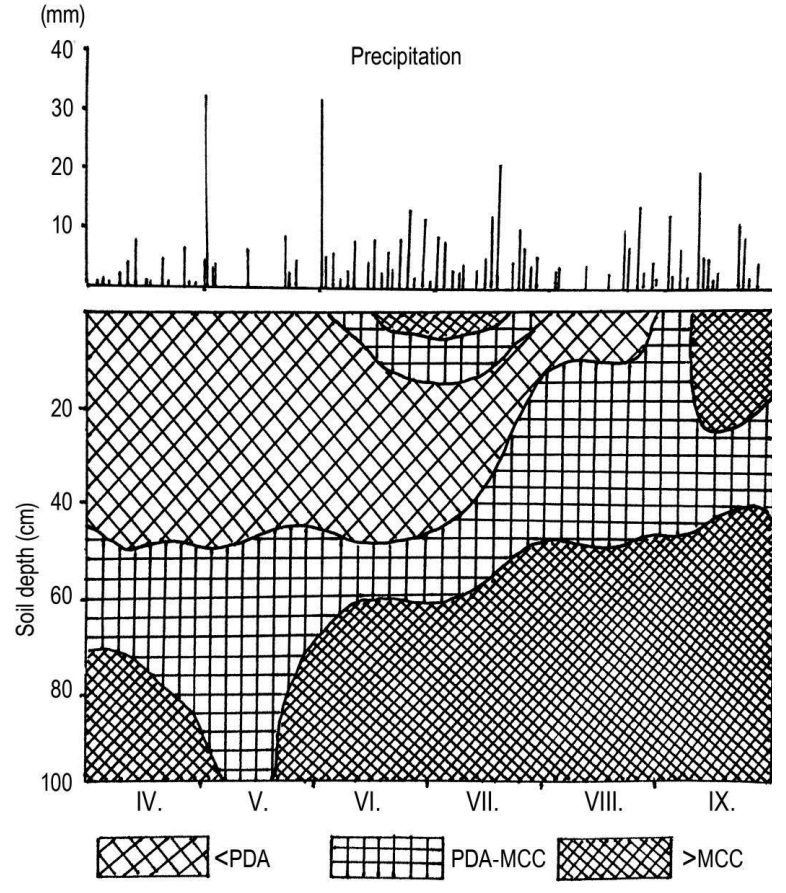

Fig. 1. Chronoizopletes for soil moisture during the growing season 1993

\section{Water accessible for plants}

During the research, the stock of usable water in the surface layer was mostly good or sufficient (>20 mm), displaying insufficiencies only following warm episodes without precipitation in July and August. Throughout the physiological profile, a good supply of usable water was maintained, most frequently by the end of May, under favourable weather conditions even by the end of June. In the summer months, the values ranged between good and sufficient (130-90 mm), falling in September 1999 in critical, collapsed unsecured period, and August 2012 and 2013 in a low stock category $(<90 \mathrm{~mm})$

\section{Ecological classification of the water regime}

In the vegetation period, three soil moisture intervals were identified under the spruce stand. The first was the obvious interval between FWC and MCC hydrolimites. This interval was present towards the end of winter and in spring months. The soil water accumulated from winter water, melting snow and higher precipitation sums. It encompassed the entire physiological soil profile of the soil, with a longer lasting occurrence in the lower third of the profile. The transition to the second semi-moisture interval with the soil moisture between the MCC and PDA hydrolimites was mostly fluent, affecting mainly the middle and deepest layers of the physiological soil profile. In the summer, there was present the third, semi-arid moisture interval between PDA

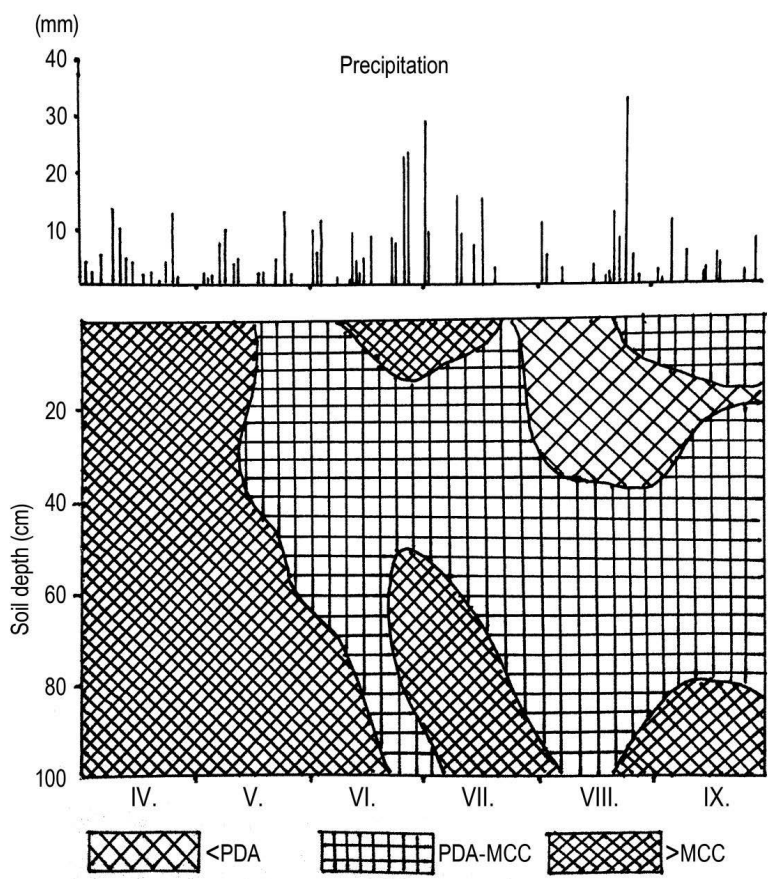

Fig. 2. Chronoizopletes for soil moisture during the growing season 1995.

and WP hydrolimits. This was the most frequent in the summer months; in the spring months, mainly in the surface soil layers were affected due to reduced winter water reserves and lacking rainfall at the beginning of the vegetation period. In an extremely dry period, moisture supplies at a depth of up to $30 \mathrm{~cm}$ dropped down to the lower half of the semi-arid moisture nterval.

\section{Conclusion}

Drought stress is regarded as one of the limiting factors for the vegetation growth. Spruce ecosystems belong to the most threatened in terms of drought effects in mountain forests.

Recognising processes and changes arising in the hydrosphere and in air and soil environment may be crucially important for ensuring the existence, growth and development of forests. These processes comprise the components of the water balance, especially evapotranspiration, runoff conditions and soil water regime.

Sustainable forest development is seriously threatened also due to the trends in hydropedological conditions. Under the influence of climate and hydropedological alterations to soil forming processes changes in temperature and humidity regime have an impact on the deterioration of the interactions in the system atmosphere - ecosystem - pedosphere.

The analysis of hydropedological research in Oravská Polhora shows that the soil moisture regime was mostly controlled by the existing soil moisture, the 
drough intensity and duration, temperature and by evapotranspiration demands.

The spruce is threatened by the drying out the soil surface layers with the major part of the tree active roots.

The increased osmotic pressure in soil solutions was caused by high amounts of contaminants accumulated in the relatively thick humus layer. This also caused the wilting poit increase.

Weather extremes and changes in the most important components of the soil water balance result in steadily increasing number and length of episodes in which the available water supply is limited or low. Changing hydropedological conditions cause physiological weakening in spruce, and debilitate their defence responses against biotic and abiotic agents. Extremely dry periods cause premature death of trees in spruce ecosystems. In terms of the global climate changes, the sustainable forest development, especially concerning the most vulnerable spruce ecosystems, can be ensured only with securing the soil quality, increasing vitality and regenerative capacity of forest ecosystems and protecting the original climax forests.

\section{Acknowledgements}

This publication is the result of implementation of the grant VEGA No. 2/0027/13, No. 02/0089/14, No. 0126/16 and projects No. - 0468-06, No. - 0456-07, No. - 0022-07 and specific research of Faculty of Forestry and Wood Sciences CULS Prague.

\section{References}

ANTAL, J., ŠpánIK, F., 1999. Hydrológia pol’nohospodárskej krajiny [Hydrology of agricultural land]. Nitra: Slovenská pol'nohospodárska univerzita. $250 \mathrm{p}$.

Bublinec, E., 1994. Koncentrácia, akumulácia a kolobeh prvkov $v$ bukovom a smrekovom ekosystéme [Concentration, accumulation and cycle of elements in beech and spruce ecosystem]. Acta Dendrologica. Bratislava: Veda. 132 p.

Drbal, J., 1965. Praktikum melioračního půdoznalství [Practicals of amelioration soil science]. Praha: SPN. $265 \mathrm{p}$.

HrašKo, J., Červenka, L., FaCeK, Z., Komár, J., NĚmeČEK, J., PospíšIL, F., SirovÝ, V., 1962. Rozbory pôd [Analysis of soils]. Bratislava: Slovenské vydavatel'stvo pôdohospodárskej literatúry. 342 p.

Klika, J., NovÁK, V., Gregor, J., 1954. Praktikum fytocenologie, ekologie, klimatologie a puidoznalstvi [Practicals of phytocenology, ecology, climatology and soil science]. Praha: ČSAV. 773 p.

Kmeť, J., Ditmarová, L., Priwitzer, T., Kurjak, D., 2009. Physiological aspects of yellowing of spruce advanced regeneration in area of the Kysucké Beskydy Mts. Beskydy-The Beskids Bulletin, 2: 29-37.
KonôPKA, B., 2009. Differences in pine root traits between Norway spruce (Picea abies [L.] Karst.) and European beech (Fagus sylvatica L.). A case study in the Kysucké Beskydy Mts. Journal of Forest Science, 55: 556-566.

Kozlowski, T.T., Kramer, P.J., Pallardy, S.G., 1991. The physiological ecology of woody plants. San Diego: Academic Press. 657 p.

KutíleK, M., 1966. Vodohospodářská pedologie [Water management related soil science]. Praha: SNTL. $275 \mathrm{p}$.

KuTíLEK, M., 1971. Ekologická klasifikace půdní vlhkosti [Ecological classification of soil moisture content]. Vodní Hospodářství, 9: 250-256.

Lorz, C., Furst, Ch., Galic, Z., Matjasic, D., PoDrazsky, V., Potocic, N., Simoncic, P., Strauch, M., VACIK, H., MaKeshin, F., 2010. GIS-based probability assessment of natural hazards in forested landscapes of Central and South-Eastern Europe. Environmental Management, 46: 920-930.

Persson, H., Fircks, Y.V., Majdi, H., Nilsson, L.O., 1995. Root distribution in a Norway spruce (Picea abies [L.] Karst.) stand subjected to drought and ammonium-sulphate application. Plant and Soil, 168-169: 161-165.

Priwitzer, T., Střelcová, K., KMeŤ, J., 2003. Ekofyziologické procesy lesných drevín [Ecophysiological processes of forest tree species]. In MinĎÁšs, J., ŠKVARENINA, J. (eds). Lesy Slovenska a globálne klimatické zmeny. Zvolen: EFRA, Lesnícky výskumný ústav, p. 44-49.

StŘelcová, K., Kučera, J., Fleischer, P., Giorgi, S., Gömöryová, E., Š́kvarenina, J., Ditmarová, L., 2009. Canopy transpiration of mountain mixed forest as a function of environmental conditions in boundary layer. Biologia, 64: 507-511.

Šach, F., Švihla, V., Černohous, V., Kantor, P., 2014. Management of mountain forests in the hydrology of a landscape, the Czech Republic - Review. Journal of Forest Science, 60: 42-50.

Šrvarenina, J., Tomlain, J., Križová, E., 2002. Klimatická vodní bilance vegetačních stupňů na Slovensku [Climatic water balance of vegetation zones in Slovakia]. Meteorologické Zprávy, 55 (4): 103-109.

ŠúTOR, J., 1994. Voda v zóne aerácie, III. Vodný zdroj prírodného zdroja [Water in the aeration zone, III. Water resource in natural environment]. In Zbornik Voda pre život. Bratislava: MPH SR, VÚVH, p. 123-128.

Šútor, J., Gomboš, M., Mati, R., 2005. Kvantifikácia pôdneho sucha [Quantification of soil drought]. In Transport vody, chemikálií a energie v systéme pôda - rastlina - atmosféra. voda. 13. posterový den̆ $s$ medzinárodnou účastou a Deň otvorených dverí na ÚH SAV. 12. november 2009. Zborník recenzovaných príspevkov. Bratislava: Ústav hydrológie SAV, Geofyzikálny ústav SAV, p. 515-523. 
TuŽInskÝ, L., 2004. Vodný režim lesných pôd [Water regime of forest soils]. Zvolen: Technická univerzita. 101 p.

VerbeeK, H., Steppe, K., Nadezdhina, N., Op De Beek, M., Deckmyn, G., Meirsonne, L., Lemeur, R., Čermák. J., Ceulemans, R., Janseens, I.A., 2007. Model analysis of the effects of atmospheric drivers in storage water use in Scots pine. Biogeosciences, 4: 657-671.

Received December 12, 2016 Accepted March 16, 2017 